\title{
Tolerance Response of some Tomato Cultivars to Salinity stress
}

\author{
Abou El Salehein E. H., M.M. El Hamadi and W.M.A. Al Gosabi
}

Plant Production Department (Vegetable), Faculty of Technology and Development, Zagazig University, Zagazig, Egypt

Received: 25 Dec. 2019 / Accepted 18 Feb. 2020 / Publication date: 25 June 2020

\begin{abstract}
Two field experiments were carried out during the two successive seasons of 2017/2018 and 2018/2019 to evaluate the two cultivars of tomato (Arwa and Codse) to tolerance of two salts ( $\mathrm{NaCl}$ and $\mathrm{CaCl}_{2}$ ) with its concentrations on vegetative growth, chemical constituents, fruit yield and quality of tomato plants. The experiment included 20 treatments; two cultivars (Arwa and Codse), two salts $\left(\mathrm{NaCl}\right.$ and $\left.\mathrm{CaCl}_{2}\right)$ and its 5 concentrations $(0.0,500,1000,1500$ and $2000 \mathrm{ppm})$. Split split plot design with three replications were used, where the main plot are the two cultivars, the two salts were distributed at the sub-plot, and the concentrations of salts are distributed in the sub-sub plots. The obtained results indicate that; the cultivar of Arwa was recorded the highest values of all the studied parameters expressed as, plant height, number of leaves, number of branches, both of fresh and dry weight of biomass, chemical contents of leaves and fruits (N, P, K, Na, protein, proline) and TSS in fruits. With increasing the concentration of salts, the studied parameters of plants were significantly decreased, expect $\mathrm{Na}$ and proline contents in tomato leaves and fruits, and TSS in fruits. In addition, the interaction between the two factors or three factors had a significant effect in some combined factors, while in most cases without any significant effect. From the forgoing results of this study, it could be concluded that Arwa cultivar could increase tomato growth and production on salt affected soils.
\end{abstract}

Keywords: Tomato cultivars, salinity stress, salts concentration

\section{Introduction}

Worldwide, tomato is one of the most important horticultural crops, for human consumption, consumed fresh, cooked or after processing; by canning, making into juice, pulp, paste, or as a variety of sauces. It is a rich source of phytochemicals such as, Lycopene, $\beta$ carotene, flavonoids, vitamin $\mathrm{C}$ and essential nutrients (Curatero and Fernandez-Munoz, 1999). Improvement for salinity tolerance would be of significant value for a moderately sensitive crop like tomato when it is grown on lands with salinity problems the growth parameter, chemical contents and fruit yield and quality will be differed from concentration to another, (Babu et al., 2012 and Helaly et al., 2017). The growth stages at which salinization is initiated, the final level of salinity achieved, and the portion of the plant to be marketed (Gharatzoulakis and Kalapaki, 2000, and Afzal et al., 2005). Cultivar differences must also be considered in evaluating crop salt tolerance, since many crops are developed from a diverse genetic base (Maas and Hoffman, 1977 and Nouck et al., 2016, Gharsallah et al., 2016).

This paper describes the response tomato cultivars (Arwa and Codse) to saline water applied at different development stage, and by establishing the maximum salt concentration in the irrigation water to maintain growth and productivity.

The objective of this study was to determine the effect of different degrees of salinity in the irrigation solution $\left(\mathrm{NaCl}\right.$ and $\left.\mathrm{CaCl}_{2}\right)$, applied at different growth stages of the two cultivars tested on vegetative growth, fruit yield and quality, and fruit and leaf chemical composition like ; N , P , K Na, proline and protein, and TSS in fruit as response of salinity stress.

\section{Material and Methods}

Two field experiments were done at Private farm in Sheiba Region, Zagazig, Sharkia Governorate, during the seasons of 2017/2018 and 2018/2019 to evaluate the two cultivars of tomato to tolerance of two salts on growth, chemical content, fruit yield and quality of tomato plants.

The chemical and physical properties of the soil are shown in Table (1).

Corresponding Author: Abou El Salehein E. H., Plant Production Department (Vegetable), Faculty of Technology and Development, Zagazig University, Zagazig, Egypt.

E-mail: eelsalehein@yahoo.co.uk 
Table 1: Physical and chemical properties of the experimental soil

\begin{tabular}{|c|c|}
\hline Properties & Values \\
\hline \multicolumn{2}{|l|}{ Physical analysis } \\
\hline Sand $(\%)$ & 76.7 \\
\hline Silt (\%) & 8.6 \\
\hline Clay (\%) & 14.7 \\
\hline Soil texture & Sandy loam \\
\hline \multicolumn{2}{|l|}{ Chemical analysis } \\
\hline Calcium carbonate $\left(\mathrm{CaCO}_{3}, \mathrm{~g} . / \mathrm{kg}\right)$ & 7.80 \\
\hline Organic matter $(\mathrm{g} / \mathrm{kg})$ & 2.11 \\
\hline pH (1: 2.5 Soil-Water suspension) & 7.94 \\
\hline Electric Conductivity (EC)(Ds/M) & 1.30 \\
\hline \multicolumn{2}{|l|}{ Soluble cations (m mol/L.) } \\
\hline Calcium $\left(\mathrm{Ca}^{++}\right)$ & 10.20 \\
\hline Magnesium $\left(\mathrm{Mg}^{++}\right)$ & 3.33 \\
\hline Sodium $\left(\mathrm{Na}^{+}\right)$ & 1.20 \\
\hline Potassium $\left(\mathrm{K}^{+}\right)$ & 1.32 \\
\hline \multicolumn{2}{|l|}{ Soluble anions (m mol/L.) } \\
\hline Carbonate $\left(\mathrm{CO}_{3}^{--}\right)$ & - \\
\hline Bicarbonate $\left(\mathrm{HCO}_{3}^{-}\right)$ & 3.90 \\
\hline Chlorine $\left(\mathrm{Cl}^{-}\right)$ & 2.85 \\
\hline Sulphate $\left(\mathrm{SO}_{4}^{--}\right)$ & 3.31 \\
\hline \multicolumn{2}{|l|}{ Available nutrients (mg/L) } \\
\hline Macro-nutrients & \\
\hline Nitrogen $(\mathrm{N})$ & 36.1 \\
\hline Phosphorus (P) & 11.1 \\
\hline Potassium (K) & 220 \\
\hline \multicolumn{2}{|l|}{ Micro-nutrients (mg/L) } \\
\hline $\mathrm{Fe}$ & 9.01 \\
\hline $\mathrm{Zn}$ & 2.20 \\
\hline $\mathrm{Cu}$ & 2.25 \\
\hline $\mathrm{Mn}$ & 4.41 \\
\hline
\end{tabular}

The seeds of two tomato (Lycopersicon esculentum MiII.) cultivars are sown in nursery on trays seeds, the plants of each cultivar were grown with three replications and transplanting after two weeks from sowing. Tomato seedlings were subjected for salt stress using 0.0 (control) and 500,1000, 1500 and $2000 \mathrm{ppm}$, both of sodium chloride $(\mathrm{NaCl})$ and calcium chloride $\left(\mathrm{CaCl}_{2}\right)$ to assess their salt tolerance on the basis of their performance in some yield-related traits such as, plant height $(\mathrm{cm})$, number of leaves, number of branches, biomass fresh weight (g), biomass dry weight (g)|, number of flowers, number of fruits, and the average of fruit $(\mathrm{g})$, at three stages of tomato development (26 days vegetative stage; 46 days, flowering stage, and 76 days, fruiting stage).

Split split-plot design with three replicates were used, where the main plot are the two cultivars, the two salts were distributed at the sub-plots, and the concentrations of salts are distributed in the sub sub-plots. The plot area was $5.40 \mathrm{~m}^{2}$ ( $3 \mathrm{~m}$ long, 3 ridges and $60 \mathrm{~cm}$ width).

The plants were subjected to salt stress at the five concentrations of salts at third stage ( 76 days after transplanting). The data of the aforementioned yield related traits were collected at the third stage of tomato growth development of the experiment and statistically analyzed according to Snedecor and Cochran (1980).

\section{Biochemical analysis of leaves and fruits}

Estimation of Proline and protein contents:

In plants, proline is synthesized from glutamic acid through a pathway catalyzed by pyrroline-5carboxylate synthetase and pyrroline-5- carboxylate reductase. Its accumulation under various abiotic stresses (heat, cold, drought, moisture and salinity) in important crop plants considered as a tolerance mechanism. It is suggested to act as an osmolyte/compatible as well as a source of nitrogen during recovery from stress. Compatible solutes act a as chemical chaper one, which protects proteins during various abiotic stresses. Proline estimation is based on the formation of brick red colored praline- 
ninhydrin complex in acidic medium. This complex is soluble in toluene and thus can be separated from aqueous phase. This ensures that there is no interference with other amino acids, which also form blue colored complex with ninhydrin. The toluene soluble brick-red colored complex absorbs at $520 \mathrm{~nm}$, (Batias et al., 1973). Proline was estimated under the two following conditions control (0 ppm), both of, $\mathrm{NaCl}$ and $\mathrm{CaCl}_{2}$ ) and salt stress $\left(500,1000,1500\right.$ and $2000 \mathrm{ppm} \mathrm{NaCl}$ and $\mathrm{CaCl}_{2}$ ). Proline concentrations were calculated and recorded using the equation of switching the spectrophotometer reading into $\mu \mathrm{g}$ proline $/ 1 \mathrm{gm}$ plant tissue for the fifth aforementioned samples. As well as, Leaves and fruit were dried in an oven at $70^{\circ} \mathrm{C}$ till constant weight to determine chemical constitute of $(\mathrm{N}, \mathrm{P}, \mathrm{K}$, and $\mathrm{Na}$ and proline).

Nitrogen (\%) was determined by micro keldjahel method according to the methods of A. O. A. C. (1995) and multiply by 6.25 to measures the protein content.

Phosphorus, potassium and sodium (\%) were determined according to the methods of A. O. A. C. (1995) .Total soluble solids (TSS\%) was determined by hand Refractomeler according to A.O.A.C. (1980). The difference between the treatments were compared using least significant differences (L.S.D) by using SAS program (SAS, Institute, 2004).

\section{Results}

\section{Vegetative growth characters:}

\section{Plant height:}

Data in Table (2) show clearly that the vegetative growth of tomato plants, i.e plant height at the three stages (at the age of 76 days from transplanting) was significantly increased with the cultivar of Arwa compared to Codse cv., in both growing seasons.

As well as, plant height of the three stages of tomato plants was significantly decreased by the salt of $\mathrm{CaCl}_{2}$ compared to the salt of $\mathrm{Na} \mathrm{Cl}$, in both seasons.

In addition, the plant height was significantly decreased by increasing the concentration of both salts from $0.0 \mathrm{ppm}$ up to $2000 \mathrm{ppm}$.

Table 2: Effect of cultivars, salts and its concentrations, as well as interaction effect on plant height of tomato plants at 76 days after transplanting during 2017/2018 and 2018/2019 seasons.

\begin{tabular}{lcc}
\hline Treatments & \multicolumn{2}{c}{ Plant height $(\mathbf{c m})$} \\
& $\mathbf{2 0 1 7 / 2 0 1 8}$ season & 2018/2019 season \\
\hline Cultivars (A) & & \\
Arwa & 82.36 & 83.84 \\
Codse & 72.69 & 77.07 \\
LSD(0.05) & 0.09 & 0.11 \\
\hline Salts (B): & & \\
NaCI & 78.56 & 80.22 \\
CaCI & 76.48 & 79.69 \\
LSD(0.05) & 0.09 & 0.11 \\
\hline Concentrations C: ppm & & \\
0.0 & 86.14 & 87.87 \\
500 & 80.25 & 83.58 \\
1000 & 76.90 & 80.07 \\
1500 & 73.91 & 76.70 \\
2000 & 70.41 & 74.05 \\
LSD(0.05) & 0.14 & 0.17 \\
\hline Interaction & & \\
AXB & $\mathrm{NS}$ & $* *$ \\
AXC & $* *$ & $* *$ \\
BXC & $* *$ & $* *$ \\
AXBXC & $* *$ & $*$ \\
\hline
\end{tabular}

Respecting the interaction between the combined effects of two or three factors was significantly, i.e. cultivars with salts, cultivars with concentration of salts, salts with its concentration and the three factors between them, in both growing seasons. 


\section{Number of leaves:}

It can be seen the data in Table (3) at the third growth stage in both growing seasons that the cultivar of Arwa was the superior resistant to salts compared with the Codse cv. of tomato, in number of leaves. The results at the same tables, revealed that number of leaves were significantly increased with the salt of $\mathrm{Na} \mathrm{Cl}$ compared to the other salt, i.e. $\mathrm{CaCl}_{2}$, although the number of leaves were decreased from the two salts compared to the untreated control. As well as, the number of tomato leaves were significantly decreased with increasing the concentration of salt from $0.0 \mathrm{ppm}$ up to $2000 \mathrm{ppm}$. Regarding the effect of interaction between both or three used factors in this study were significantly affected in number of leaves of tomato plants.

Table 3: Effect of cultivars, salts and its concentrations, as well as interaction effect on number of leaves plants at 76 days after transplanting during 2017/2018 and 2018/2019 seasons.

\begin{tabular}{|c|c|c|}
\hline \multirow{2}{*}{ Treatments } & \multicolumn{2}{|c|}{ Number of leaves } \\
\hline & $2017 / 2018$ season & 2018/2019 season \\
\hline \multicolumn{3}{|l|}{ Cultivars (A) } \\
\hline Arwa & 52.83 & 55.08 \\
\hline Codse & 48.78 & 51.62 \\
\hline $\operatorname{LSD}(0.05)$ & 0.08 & 0.07 \\
\hline \multicolumn{3}{|l|}{ Salts (B): } \\
\hline $\mathrm{NaCI}$ & 51.98 & 54.22 \\
\hline $\mathrm{CaCI}_{2}$ & 49.63 & 52.48 \\
\hline $\operatorname{LSD}(\mathbf{0 . 0 5})$ & 0.08 & 0.07 \\
\hline \multicolumn{3}{|c|}{ Concentrations C: ppm } \\
\hline 0.0 & 58.37 & 59.24 \\
\hline 500 & 55.50 & 55.76 \\
\hline 1000 & 50.33 & 53.52 \\
\hline 1500 & 46.64 & 50.19 \\
\hline 2000 & 43.19 & 48.04 \\
\hline $\operatorname{LSD}(0.05)$ & 0.12 & 0.11 \\
\hline \multicolumn{3}{|l|}{ Interaction } \\
\hline $\mathrm{AXB}$ & $* *$ & $* *$ \\
\hline $\mathrm{AXC}$ & $* *$ & $* *$ \\
\hline $\mathrm{BXC}$ & $* *$ & $* *$ \\
\hline $\mathrm{AXBXC}$ & $* *$ & $* *$ \\
\hline
\end{tabular}

\section{Number of branches:}

It is evident from data in Table (4) at the third stage of tomato development (76 days after transplanting) that Arwa is the resistant cultivar overcome the salt stress than Codse cv. in the first season only, because the second season was did not offer any significant between both of two cultivars. Moreover, at the same table number of branches was recorded the highest value as response of the untreated control with any salts addition, but with applied salts $\left(\mathrm{Na} \mathrm{Cl}\right.$ and $\left.\mathrm{Ca} \mathrm{Cl}_{2}\right)$, the number of branches was recorded the lowest values, respectively.

As the result, of salts concentrations, it is evident from the data in the same table, that applying the different concentrations of salts had a significant decreases with increasing the concentration from $0.0 \mathrm{ppm}$ up to the highest concentration, i.e. $2000 \mathrm{ppm}$.

Regarding the effect of interaction between the two or three used factors in this study, there are a significant effect on number of branches in the first season only, and did not appear any significant effect in the second season of this study.

\section{Biomass fresh weight:}

Data in Table (5) at the third stage of tomato development (76 days after transplanting) revealed that biomass fresh weight of tomato plants cv. Arwa had a highest recorded than Codse cv., which recorded the lowest values in biomass fresh weight. With respect to the effect of the two salts on both cultivars in biomass fresh weight, in the same tables, data illustrated that the control treatment caused the highest values, followed by $\mathrm{Na} \mathrm{Cl}, \mathrm{CaCl} 2$ salts with gradually decreased, respectively.

Resecting the concentrations, table firmed that the highest concentration of salts, i.e. $2000 \mathrm{ppm}$ caused the lowest values in biomass fresh weight of tomato plants. 
Data recorded in the same tables, indicate that the interaction between the two or three studied factors significantly affect on biomass fresh weight of tomato plant, but caused un significant effect at the table (5) with cultivar X salts, and with the three studied factors, i.e. cultivar, salts, and its concentrations.

Table 4: Effect of cultivars, salts and its concentrations, as well as interaction effect on number of branches plants at 76 days after transplanting during 2017/2018 and 2018/2019 seasons.

\begin{tabular}{lcc}
\hline Treatments & \multicolumn{2}{c}{ Number of branches } \\
2018/2019 season
\end{tabular}

Table 5: Effect of cultivars, salts and its concentrations, as well as interaction effect on biomass fresh weight plants at 76 days after transplanting during 2017/2018 and 2018/2019 seasons.

\begin{tabular}{|c|c|c|}
\hline \multirow{2}{*}{ Treatments } & \multicolumn{2}{|c|}{ Biomass fresh weight $(g)$} \\
\hline & $2017 / 2018$ season & $2018 / 2019$ season \\
\hline \multicolumn{3}{|l|}{ Cultivars (A) } \\
\hline Arwa & 1979.066 & 2041.066 \\
\hline Codse & 1896.233 & 2020.133 \\
\hline $\operatorname{LSD}(\mathbf{0 . 0 5})$ & 11.336 & 1.612 \\
\hline \multicolumn{3}{|l|}{ Salts (B): } \\
\hline $\mathrm{NaCI}$ & 1977.600 & 2034.933 \\
\hline $\mathrm{CaCI}_{2}$ & 1897.700 & 2026.266 \\
\hline $\operatorname{LSD}(0.05)$ & 11.334 & 1.612 \\
\hline \multicolumn{3}{|l|}{ Concentrations $\mathrm{C}: \mathrm{ppm}$} \\
\hline 0.0 & 2221.500 & 2223.167 \\
\hline 500 & 2135.166 & 2157.417 \\
\hline 1000 & 2074.583 & 2133.000 \\
\hline 1500 & 1798.583 & 1923.083 \\
\hline 2000 & 1458.416 & 1716.333 \\
\hline $\operatorname{LSD}(0.05)$ & 17.924 & 2.520 \\
\hline \multicolumn{3}{|l|}{ Interaction } \\
\hline $\mathrm{AXB}$ & $* *$ & $\mathrm{NS}$ \\
\hline $\mathrm{AXC}$ & $* *$ & $* *$ \\
\hline $\mathrm{BXC}$ & $* *$ & $* *$ \\
\hline $\mathrm{AXBXC}$ & $* *$ & NS \\
\hline
\end{tabular}

\section{Biomass dry weight:}

Data in Table (6) at the three stage of tomato development indicated that Arwa cv. recorded a highest values in biomass dry weight of tomato plants compared to the other cultivar, i.e. Codse, which recorded the lowest values for resistancing the salt stress. In another way, $\mathrm{Na} \mathrm{Cl}$ salt caused a highest values in biomass dry weight of tomato plants than $\mathrm{Ca} \mathrm{Cl}_{2}$ salt (at the same table, 6).

Regarding the effect of different concentrations of the two salts on biomass dry weight of tomato plants in the same table, there are a significantly increased by decreasing the concentration of salts 
from $2000 \mathrm{ppm}$ down to $500 \mathrm{ppm}$, then $0.0 \mathrm{ppm}$ (control treatment). The interactions between both of cultivars $\mathrm{x}$ salts caused an increase in this stage of tomato development, i.e. 76 days after transplanting. As well as, the other interaction between two or three factors caused an increases in biomass dry weight of tomato plants.

Table 6: Effect of cultivars, salts and its concentrations, as well as interaction effect on biomass dry weight plants at 76 days after transplanting during 2017/2018 and 2018/2019 seasons.

\begin{tabular}{lcc}
\hline \multirow{2}{*}{ Treatments } & \multicolumn{2}{c}{ Biomass dry weight(g) } \\
\cline { 2 - 3 } Cultivars (A) & $\mathbf{2 0 1 7 / 2 0 1 8}$ season & $\mathbf{2 0 1 8 / 2 0 1 9}$ season \\
Arwa & 1232.200 & 1255.333 \\
Codse & 1125.766 & 1131.233 \\
LSD(0.05) & 0.971 & 1.311 \\
\hline Salts (B): & 1181.733 & 1198.266 \\
NaCI & 1176.233 & 1188.300 \\
CaCI & 0.970 & 1.310 \\
LSD(0.05) & & \\
\hline Concentrations C: $\mathbf{p p m}$ & 1263.166 & 1281.333 \\
0.0 & 1187.333 & 1203.583 \\
500 & 1174.666 & 1177.833 \\
1000 & 1166.583 & 1165.167 \\
1500 & 1103.166 & 1138.500 \\
2000 & 1.535 & 2.075 \\
LSD(0.05) & & $* *$ \\
\hline Interaction & $* *$ & $* *$ \\
AXB & $* *$ & $* *$ \\
AXC & $* *$ & $* *$ \\
BXC & $*$ & \\
AXBXC & & \\
\hline
\end{tabular}

\section{Flowering and fruit yield:}

\section{Number of flowers:}

The number of tomato flowers were significantly different between the two cultivars exposed to the Arwa cultivar (Table, 7). The highest values of number of flowers were recorded with cv. Arwa during the vegetative stage (76 days at the fruiting stage). In the same table, salinity stress with two salts at different growth stages significantly affected the number of flowers. The response of cultivars to $\mathrm{Na} \mathrm{Cl}$ were recorded highest values compared to another salt, i.e. $\mathrm{CaCl}_{2}$.

Respecting the concentrations of the two salts, the number of tomato flowers significantly increased by decreasing the concentration of salts to $500 \mathrm{ppm}$, then $0.0 \mathrm{ppm}$ (the control treatment). The highest number of flowers were obtained with the control treatment, while the lowest values were obtained with the treatment of $2000 \mathrm{ppm}$ of both salts $\left(\mathrm{Na} \mathrm{Cl}\right.$ and $\left.\mathrm{Ca} \mathrm{Cl}_{2}\right)$.

Regarding to the interaction effect between the two factors or three factors, there are some significantly different between the three factors in the second season.

\section{Number of fruits:}

All of the number of fruits were highest in cultivar Arwa compared to Codse cv. of tomato plants (Table, 8). A comparison of the two cultivars that exposed to salinity stress at different growth stages showed that the number of fruits exhibited the highest number with $\mathrm{Na} \mathrm{Cl}$ salt compared to the another salt $\left(\mathrm{CaCl}_{2}\right.$.) at both growing seasons.

Concerning the effect of the concentrations of salts on number of fruits at the three stages of development tomato plants at both growing seasons, the number of fruits were gradually decreased by increasing the concentration of salts from 0.0 up to $2000 \mathrm{ppm}$.

The highest values of number of fruits were obtained with the control treatment, while the lowest values of number of tomato fruits were obtained with the concentration of $2000 \mathrm{ppm}$ from both salts. 
The combined effect of interaction between the two or three studied factors were no significantly differences, in most cases at both growing seasons of this study.

Table 7: Effect of cultivars, salts and its concentrations, as well as interaction effect on number of flowers plants at 76 days after transplanting during 2017/2018 and 2018/2019 seasons.

\begin{tabular}{|c|c|c|}
\hline \multirow{2}{*}{ Treatments } & \multicolumn{2}{|c|}{ Number of flowers } \\
\hline & $2017 / 2018$ season & 2018/2019 season \\
\hline \multicolumn{3}{|l|}{ Cultivars (A) } \\
\hline Arwa & 27.95 & 28.74 \\
\hline Codse & 26.17 & 27.40 \\
\hline $\operatorname{LSD}(0.05)$ & 0.07 & 0.34 \\
\hline \multicolumn{3}{|l|}{ Salts (B): } \\
\hline $\mathrm{NaCI}$ & 27.74 & 28.92 \\
\hline $\mathrm{CaCI}_{2}$ & 26.38 & 27.22 \\
\hline $\operatorname{LSD}(0.05)$ & 0.07 & 0.34 \\
\hline \multicolumn{3}{|c|}{ Concentrations C: ppm } \\
\hline 0.0 & 33.86 & 32.82 \\
\hline 500 & 29.60 & 30.11 \\
\hline 1000 & 27.56 & 28.11 \\
\hline 1500 & 24.06 & 26.37 \\
\hline 2000 & 20.21 & 22.94 \\
\hline $\operatorname{LSD}(0.05)$ & 0.11 & 0.54 \\
\hline \multicolumn{3}{|l|}{ Interaction } \\
\hline $\mathrm{AXB}$ & $* *$ & $*$ \\
\hline $\mathrm{AXC}$ & $* *$ & $* *$ \\
\hline $\mathrm{BXC}$ & $* *$ & $* *$ \\
\hline $\mathrm{AXBXC}$ & $* *$ & $*$ \\
\hline
\end{tabular}

Table 8: Effect of cultivars, salts and its concentrations, as well as interaction effect on number of fruits plants at 76 days after transplanting during 2017/2018 and 2018/2019 seasons.

\begin{tabular}{|c|c|c|}
\hline \multirow{2}{*}{ Treatments } & \multicolumn{2}{|c|}{ Number of fruits } \\
\hline & $2017 / 2018$ season & 2018/2019 season \\
\hline \multicolumn{3}{|l|}{ Cultivars (A) } \\
\hline Arwa & 22.59 & 24.03 \\
\hline Codse & 19.88 & 22.08 \\
\hline $\operatorname{LSD}(\mathbf{0 . 0 5})$ & 0.06 & 0.08 \\
\hline \multicolumn{3}{|l|}{ Salts (B): } \\
\hline $\mathrm{NaCI}$ & 22.24 & 23.52 \\
\hline $\mathrm{CaCI}_{2}$ & 20.23 & 22.60 \\
\hline $\operatorname{LSD}(\mathbf{0 . 0 5})$ & 0.06 & 0.08 \\
\hline \multicolumn{3}{|c|}{ Concentrations C: ppm } \\
\hline 0.0 & 26.74 & 27.35 \\
\hline 500 & 23.33 & 24.79 \\
\hline 1000 & 20.65 & 23.39 \\
\hline 1500 & 18.65 & 20.89 \\
\hline 2000 & 16.82 & 18.87 \\
\hline $\operatorname{LSD}(0.05)$ & 0.10 & 0.12 \\
\hline \multicolumn{3}{|l|}{ Interaction } \\
\hline $\mathrm{AXB}$ & $* *$ & NS \\
\hline $\mathrm{AXC}$ & $* *$ & $* *$ \\
\hline $\mathrm{BXC}$ & $* *$ & $* *$ \\
\hline $\mathrm{AXBXC}$ & $* *$ & NS \\
\hline
\end{tabular}

\section{Mean fruit weight:}

Data in Table 9, show clearing that the mean fruit weight was highest by the cultivar. Arwa compared to Codse cv. of tomato plants. $\mathrm{NaCl}$ salt were recorded highest values of mean fruit weight in both cultivars compared to the other salt, i.e. $\mathrm{CaCl}_{2}$.

A comparison of treatments that exposed plants to salinity stress with different concentrations at fruit stage illustrated that the main fruit weight exhibited the highest values with the control treatment, while the highest concentration of salts $(2000 \mathrm{ppm})$ was recorded the lowest values of main fruit weight of tomato. All the interaction effect between the studied factors were recorded significantly differences in main fruit weight in both growing seasons. 
Table 9: Effect of cultivars, salts and its concentrations, as well as interaction effect on mean fruit height plants at 76 days after transplanting during 2017/2018 and 2018/2019 seasons.

\begin{tabular}{|c|c|c|}
\hline \multirow{2}{*}{ Treatments } & \multicolumn{2}{|c|}{ Mean fruit weight (g) } \\
\hline & $2017 / 2018$ season & 2018/2019 season \\
\hline \multicolumn{3}{|l|}{ Cultivars (A) } \\
\hline Arwa & 103.02 & 106.15 \\
\hline Codse & 96.35 & 105.58 \\
\hline $\operatorname{LSD}(0.05)$ & 0.14 & 0.20 \\
\hline \multicolumn{3}{|l|}{ Salts (B): } \\
\hline $\mathrm{NaCI}$ & 101.60 & 108.41 \\
\hline $\mathrm{CaCI}_{2}$ & 97.77 & 103.31 \\
\hline $\operatorname{LSD}(0.05)$ & 0.14 & 0.21 \\
\hline \multicolumn{3}{|c|}{ Concentrations C: ppm } \\
\hline 0.0 & 124.44 & 125.40 \\
\hline 500 & 107.41 & 110.76 \\
\hline 1000 & 98.50 & 106.38 \\
\hline 1500 & 88.57 & 100.35 \\
\hline 2000 & 79.50 & 86.41 \\
\hline $\operatorname{LSD}(0.05)$ & 0.23 & 0.32 \\
\hline \multicolumn{3}{|l|}{ Interaction } \\
\hline $\mathrm{AXB}$ & $* *$ & $* *$ \\
\hline $\mathrm{AXC}$ & $* *$ & $* *$ \\
\hline $\mathrm{BXC}$ & $* *$ & $* *$ \\
\hline $\mathrm{AXBXC}$ & $* *$ & $* *$ \\
\hline
\end{tabular}

\section{Chemical constituents of tomato leaves:}

It is evident from data in table (10) show the effect of salts and its concentrations on the chemical composition of the two studied cultivars, i.e. Arwa and Codse. Data revealed that Arwa cultivar had a high chemical contents in $\mathrm{N}, \mathrm{P}, \mathrm{K}, \mathrm{Na}$, proline and protein of leaves compared to the other cultivar, i.e. Codse cv. in both growing seasons. Arwa cultivar improved, the suitable variety to tolerance salinity stress in the studied two salts $\left(\mathrm{Na} \mathrm{Cl}\right.$ and $\left.\mathrm{Ca} \mathrm{Cl}_{2}\right)$ in both growing seasons of this study. The addition of the two salts to the both cultivars decreased N, P, K and protein in tomato leaves, and increased the leaves content of $\mathrm{Na}$ and proline. The Arwa cv., superior tolerance than Codse cv., for all the chemical contents of leaves. With increasing the concentration of salts from 0.0 up to high concentration (2000 ppm) the minerals contents $(\mathrm{N}, \mathrm{P}, \mathrm{K})$ and protein were decreased, while the $\mathrm{Na}$ and proline were increased. Regarding the interaction effect of the two combined effect or three factors on the chemical leaves content, the plants responded to salts, without any significant differences, expect in $\mathrm{N}$ and protein. The simulative effect of $\mathrm{cv}$. Arwa compared to cv. Codse, when they received the application of salts and its concentrations may be due to genitic variation between the both cultivar (Dimirkaya et al., 2014).

The Arwa cultivar, being the most effective in tolerance salinity stress, and from the ways to resistant the salinity harm full that produce some organic substance to kept the self -life of plants long time such as, proline and increasing the Na concentration (Rahman et al., 2018, Ghoname et al., 2019 and Demirkaya, 2014). The results are in a good line with those reported by Babu et al., (2012).

\section{Chemical constituents of fruits:}

The present study of chemical parameter of the two cultivars of fruits tomato plants are shown in table (11), which included N, P, K, Na, proline, protein and TSS contents, reflected that the cultivar Arwa is a good variety to tolerance the salinity stress over than Codse cv., in all the studied chemical constituents in fruit. The salts with its concentrations caused a significantly decreased in content of $\mathrm{N}$, $\mathrm{P}, \mathrm{K}$ and protein, while it increased in $\mathrm{Na}$, proline and TSS in tomato fruits.

Regarding to the interaction effect of the two or the three factors of this study, there is non significantly differences in most cases. 
Table 10: Effect of cultivars, salts and its concentrations, as well as interaction effect on chemical contents of tomato leaves during the second season 20/8/2019.

\begin{tabular}{|c|c|c|c|c|c|c|}
\hline \multirow{2}{*}{ Treatments } & \multicolumn{6}{|c|}{ Chemical contents of leaves $(\%)$} \\
\hline & $\mathbf{N}$ & $\mathbf{P}$ & $\mathbf{K}$ & $\mathbf{N a}$ & Proline & Protein \\
\hline \multicolumn{7}{|c|}{ Cultivars (A) } \\
\hline Arwa & 2.220 & 0.285 & 2.590 & 0.514 & 1.921 & 13.875 \\
\hline Codse & 2.030 & 0.259 & 2.123 & 0.486 & 1.683 & 12.687 \\
\hline $\operatorname{LSD}(\mathbf{0 . 0 5})$ & 0.028 & 0.003 & 0.043 & 0.007 & 0.001 & 0.180 \\
\hline \multicolumn{7}{|l|}{ Salts (B): } \\
\hline $\mathrm{NaCI}$ & 2.213 & 0.278 & 2.450 & 0.482 & 1.798 & 13.833 \\
\hline $\mathrm{CaCI}_{2}$ & 2.037 & 0.266 & 2.266 & 0.817 & 1.806 & 12.729 \\
\hline $\operatorname{LSD}(0.05)$ & 0.029 & 0.004 & 0.044 & 0.007 & 0.001 & 0.180 \\
\hline \multicolumn{7}{|c|}{ Concentrations C: ppm } \\
\hline 0.0 & 2.958 & 0.345 & 2.916 & 0.223 & 0.594 & 18.489 \\
\hline 500 & 2.583 & 0.311 & 2.675 & 0.316 & 0.865 & 16.145 \\
\hline 1000 & 2.150 & 0.271 & 2.350 & 0.435 & 1.474 & 13.437 \\
\hline 1500 & 1.625 & 0.230 & 2.058 & 0.625 & 2.071 & 10.156 \\
\hline 2000 & 1.309 & 0.204 & 1.791 & 0.902 & 4.007 & 8.177 \\
\hline $\operatorname{LSD}(0.05)$ & 0.045 & 0.006 & 0.069 & 0.012 & 0.002 & 0.284 \\
\hline \multicolumn{7}{|l|}{ Interaction } \\
\hline $\mathrm{AXB}$ & * & NS & NS & NS & NS & $*$ \\
\hline $\mathrm{AXC}$ & $*$ & $*$ & NS & NS & $* *$ & $*$ \\
\hline $\mathrm{BXC}$ & $* *$ & NS & NS & $*$ & $* *$ & $* *$ \\
\hline $\mathrm{AXBXC}$ & $*$ & NS & NS & NS & NS & $*$ \\
\hline
\end{tabular}

Table 11: Effect of cultivars, salts and its concentrations, as well as interaction effect on chemical contents of tomato fruits during the second season 20/8/2019.

\begin{tabular}{|c|c|c|c|c|c|c|c|}
\hline \multirow{2}{*}{ Treatments } & \multicolumn{7}{|c|}{ Chemical contents of fruits (\%) } \\
\hline & $\mathbf{N}$ & $\mathbf{P}$ & $\mathbf{K}$ & $\mathrm{Na}$ & Proline & Protein & TSS \\
\hline \multicolumn{8}{|l|}{ Cultivars (A) } \\
\hline Arwa & 2.040 & 0.264 & 2.390 & 0.467 & 1.043 & 12.750 & 7.663 \\
\hline Codse & 1.820 & 0.244 & 1.943 & 0.459 & 0.976 & 11.375 & 7.533 \\
\hline $\operatorname{LSD}(0.05)$ & 0.039 & 0.004 & 0.040 & 0.008 & 0.001 & 0.246 & 0.008 \\
\hline \multicolumn{8}{|l|}{ Salts (B): } \\
\hline $\mathrm{NaCI}$ & 1.986 & 0.261 & 2.270 & 0.454 & 1.004 & 12.416 & 7.582 \\
\hline $\mathrm{CaCI}_{2}$ & 1.873 & 0.247 & 2.063 & 0.471 & 1.015 & 11.708 & 7.614 \\
\hline $\operatorname{LSD}(\mathbf{0 . 0 5})$ & 0.039 & 0.003 & 0.040 & 0.007 & 0.001 & 0.247 & 0.008 \\
\hline \multicolumn{8}{|c|}{ Concentrations C: ppm } \\
\hline 0.0 & 2.783 & 0.322 & 2.700 & 0.203 & 0.514 & 17.395 & 5.615 \\
\hline 500 & 2.258 & 0.285 & 2.483 & 0.287 & 0.599 & 14.114 & 6.437 \\
\hline 1000 & 1.966 & 0.255 & 2.158 & 0.377 & 1.206 & 12.291 & 7.219 \\
\hline 1500 & 1.475 & 0.215 & 1.858 & 0.575 & 1.834 & 9.218 & 8.855 \\
\hline 2000 & 1.166 & 0.191 & 1.633 & 0.873 & 2.895 & 7.291 & 9.763 \\
\hline $\operatorname{LSD}(0.05)$ & 0.062 & 0.006 & 0.063 & 0.011 & 0.002 & 0.389 & 0.013 \\
\hline \multicolumn{8}{|l|}{ Interaction } \\
\hline $\mathrm{AXB}$ & NS & NS & NS & NS & NS & NS & NS \\
\hline $\mathrm{AXC}$ & $*$ & NS & NS & $*$ & $* *$ & $*$ & $* *$ \\
\hline $\mathrm{BXC}$ & $*$ & $*$ & NS & NS & $* *$ & $*$ & $*$ \\
\hline $\mathrm{AXBXC}$ & $*$ & NS & NS & NS & $* *$ & $*$ & NS \\
\hline
\end{tabular}

\section{Discussion}

The response of plant growth characters were differed from cultivar to another, specially when the plants grown under salt stress conditions. In study the plant growth characters of tomato plants (plant height (Table, 2); number of leaves (Table, 3); number of branches (Table, 4); biomass fresh weight (Table,5), and biomass dry weight (Table,6) significantly increased with Arwa c. v., compared to the other cultivar, i.e. Codse.

Aline of evidence suggests that, depending on plant species and variety, there is great variability in resistance to salinity (Ashraf and Foolad, 2007, and Rahman et al., 2018). Besides of that, different tolerance ranges of the two studied cultivars to salinity were also found based on the morphological features of the stage of tomato plants (76 days after transplanting, in this study), as well as, the cultivar had a genetic properties differed from variety to another to tolerance salinity (Siddiky et al., 2012). 
These results are in concurrence with those recorded by Maas and Hoffman, (1977), Demirkaya, (2014), Gharsallah et al., (2016) and Nouck et al., (2016).

Plant growth parameters (plant height, number of leaves, number of branches, biomass fresh weight and biomass dry weight) are negatively affected by the two salts $\left(\mathrm{NaCl}\right.$ and $\left.\mathrm{CaCl}_{2}\right)$, which reduced the different parts of plant and caused the photosynthesis reduction tissues expansion reduction and cell divided inhibition and photosynthetic activity (Zhang et al., 2016 a), who working on $\mathrm{NaCl}$ salt, and Hossain and Nonam, 2012, who working on Ca salt).

The present results resemble with those noticed by Babu et al., (2012) and Helaly et al., (2017). The concentration of salts at different development stages of tomato plants decreases the plant growth parameters by affecting in plant physiological and bio chemical processes (Karim et al., 1993).

With increasing the concentrate of salt significantly decreased plant growth parameters as well as, show in all tables at the different stages of tomato development (Gharatzoulakis and Kalapaki, 2000 and Afzal et al., 2005). These results are in accordance with those mentioned by Rahman et al. (2018) and Zhang et al. (2016).

It can be seen from the data in tables (7), (8) and 9, that number of flowers, number of fruits, and mean fruit weight, respectively, there is great variability in resistance to salinity between cultivars (Ashraf and Foolad, 2007). The highest values of the abovementioned characters were obtained with cv. Arwa compared to Codse cv., the Arwa cultivar had a genetic tolerant to salinity stress higher than Codse cultivar, which based on the morphological features of different growth stages of tomato plants (Chookhampaeng et al., 2007).

It is noted that with increasing the concentration of salinity, growth-affecting parameters change (plant height, number of leaves, number of branches, both fresh and dry weight of biomass), and ultimately number of flowers, number of fruits, and fruit production halves (Rahman et al., 2018). These results are in affirmed with those recorded by (Chookhampaeng et al., 2007, Najla et al., 2008, and Siddiky et al., 2012).

The simulative effect of cv. Arwa compared to cv. Codse, when they received the application of salts and its concentrations may be due to genitic variation between the both cultivar (Dimirkaya et al., 2014).

Arwa cultivar is the being effective in tolerance of salinity stress which had a genetic characters to resistance the salinity, consequently in reverse to the parameters of vegetative growth, chemical constituents and fruit quality (In all tables in this study).

Moreover, salinity can decrease root water uptake through its osmotic effects and subsequently induce water stress. Fruit quality is the only parameters which is positively affected with increased salinity (Zhang et al., 2016). In addition, plants under salinity stress uptake lower level of $\mathrm{k}$ with increasing uptake. Levels of $\mathrm{Na}$ (Mugdal et al., 2010).

These results followed the same patterns of Helaly et al., (2017), Islam et al., (2018), and Ghoname et al., (2019), they concluded that the salinity application is an effective method for the improvement of fruit quality particularly in terms of chemical contents and bioactive substances.

\section{Conclusion}

It could be concluded the cv. Arwa relatively higher tolerance of to all growth parameters and fruit yield and all yield quality components than others, it can be suggesting that Arwa cultivar could increase tomato growth and production on salt affected soils.

\section{References}

Afzal, J., S. A. M. Basra, and A. Iqbal, 2005. The effect of growth regulators on seedling vigor of wheat under salinity stress. Journal of Stress Physiology \& Biochemistry, 1: 6 - 14.

A.O.A.C. 1980. Association of Official Methods of Analysis .Analytical Official Analytical Chemists. Chamists, $13^{\text {th }}$ Ed.

A.O.A.C., Association of official Agricultural chemists, 1995. Official methods of analysis $10^{\text {th }}$ ed. A.O.A.C., wash, D.C.

Ashraf, M., andM. R. Foolad, 2007. Improving plant abiotic stress resistance by exogenous application of osmoprotectants glycine betaine and proline. Environs Exp. Bot. 59:206-216. 
Babu, M. A., D. Singh, and K. M. Gothandam, 2012. The effect of salinity on growth, hormones and mineral elements in leaf and fruit of tomato cultivar PKM1.The journal of Animal \& plant Sciences, 22(1):159-164.

Batias, L.S., R.P. Waldran and I.D. Teare, 1973. Rapid determination of free proline for water stress studies. Plant Soil 39: 205-208.

Chartzoulakis, K. and G. Klapaki, 2000. Response of two greenhouse pepper hybrids to $\mathrm{NaCl}$ salinity during different growth stages; Sci. Hort., 86: 247-260.

Chookhampaeng, S., W. Pattanagul, and P. Theera kulpisut, 2007. Screening some tomato comercil cultivars from Thailand for salinity tolerance. Asian J. plant sci., 6: 788-794.

Curatero, J., and R. Fernandez - Munoz, 1999.Tomato and Salinity . Scientia Horticulturae, 78: 83-125.

Demirkaya, M., 2014. Improvement in tolerance to salt stress during tomato cultivation Turkish Journal of Biology, 38:193.199.

Gharsallah, Ch., H. Fakhfakh, D. Grubb, and F. Gorsan, 2016. Effect of salt stress on ion concentration, proline content, antioxidant enzyme activities and gene expression in tomato cultivars. Annals of Botany Company Journals, 8:1093- 1104.

Ghoname, A. A., Z. F. Fawzy, and A. M. Bassiony, 2019. Adverse positive effect of salinity stress on tomato fruit quality. Acta scientific Agriculture, 3(8): 66-69.

Gogile, A., M. Andargie, and M. Muthuswamy, 2013. Screening selected genotypes of cowpea (Vigna unguiculata L.) for salt tolerance during seedling growth stage; Pak J. Biol Sci., 16 (14): 671-9.

Helaly, A. A., Y. Goda, and S.A. El-Rahim, 2017. Effect of irrigation with different levels of saline water type on husk tomato productivity. Adv. Plants Agric. Res., 6(4): 113-120.

Hossain, M. M., and H. Nonami, 2012. Effect of salt stress on physiological response of tomato fruit grown in hydroponic culture system Hort. Sci. (Prague), 39(1): 26-32.

Islam, M. Z., M. A. Mele, K. Choi, and H. kang, 2018. Nutrient and salinity concentration effect on quality and storability of cherry tomato fruits grown by hydroponic system. Bragantia, 77 (2): p23- 728.

Karim, M. A., E. Nawata, and S. Sigenaga, 1993. Effects of salinity and water stress on the growth , yield and physiological characteristics in hexaploid trticale, Jpn. J. Trop. Agric., 37: 46 - 52.

Läuchli A. and S.R. Grattan, 2007. Plant growth and development under salinity stress; Advances in molecular breeding toward drought and salt tolerance; chapter 1:1-32.

Maas, E. V., and G. J. Hoffman, 1977. Crop salt tolerance current assessment. Journal of Irrigation and Drainage Division, 103;115-134.

Mugdal, V., N. Madaan and A. Mugdal, 2010. Biochemical mechanisms of salt tolerance in plants: a review. International Journal of Botany, 6: $136-143$.

Najla, S., G. Vercambre, L. Pages, and D. Grasselly, 2008. Effect of salinity on tomato plant architecture. Acta Horticulturae, 801(801): 1183-1190.

Nouck, A. E., V. D. Taffpuo, 5. Tsoata, D.S. Dibong, S.I. Nguemezi, I. Gouade and E-Youmbi , 2016. Growth, biochemical constituents, micronutrients uptake, and yield response of six tomato (Lycopersicom esculentum L.) cultivars grown under salinity stress. Journal of Agronomy, 15(2): 58-67.

Rahman, M. Md., M. Hassain, X. F. B. Hossain, Md. T. Sikder, M. Shammi, Md. Rasheduzzanan, M. A. Uddin, 2018. Effects of NaCl-salinity on tomato (Lycopersicon esculentum Mill.) plants in a pot experiment-Open Agriculture, 3: 578-585.

SAS, 2004. SAS user Guids- version 9.2, SAS Institute Inc. Cary, North USA, Carolina.

Siddiky, M. A., P. K. Sardar, M. M. Hossain, M. S. khan, and M. K. Uddin, 2012. Sereening of different tomato varieties in saline areas of Bangladesh. Int.J. Agric. Res. Innov. Technol., 2: 13-18

Snedecor, G. W., and W. G Cochran, 1980. Statistical Method $7^{\text {th }}$ Ed. Iowa state Univ., Press Amer., Iowa, USA.

Zeinolabedin, J., 2012. The Effects of Salt stress on plant growth; Technical Journal of Engineering and Applied Sciences, 2 (1): 7-10.

Zhang, P., M. Senge, and Y. Dai, 2016-a. Effect of salinity stress on growth, yield and water use efficiency of tomato under hydroponics system. Reviews in Agricultural Science, 4: 46-55.

Zhang, P., M. Senge, Y. Dai (2016-b).Effects of salinity stress at different growth stages on tomato growth, yield and water - use efficiency. Communication in Soil Science and Plant Analysis, 48 96):624-634. 